Hindness I bad the opportunity of penetrating into the arcana of the Hygienic Institute of Berlin and seeing most beautiful researches being carried on in that institution, of which Koch is the inspiring genius. I saw things which, while they excited my admiration, made me also feel ashamed that we in this country, from one circumstance or another, are so greatly behind our German brethren. The researches to which I desire specially to refer are still in progress, and fresh facts are accumulating day by day. As they have not yet been published, I am not at liberty to mention details, but there can be no harm in my saying thus much, that I saw, in the case of two of the most virulent infective diseases to which man is liable, the course of the otherwise deadly disease cut short in the animals on which the experiments were per. formed by the injection of a small quantity of a material perfectly constant in character, an inorganic chemical substance as easily obtainerl as any article in the materia medica. And not only so, but by means of the same substance these animals were rendered incapable of taking the disease under the most potent inoculations; perfect immunity was conferred upon them. I suspect that before many weeks have passed the world will be startled by the disclosure of these facts. If they can be applied to man-though our experience of the different behaviour of Koch's Huid in guinea-pigs and in the human subject makes this a matter of uncertainty until tested by experiment-but if they can be applied to man, the world will be astonished, and the beneficence of these researches will be recognised on every hand. At the present time Koch is engaged in the earnest endeavour to produce his remedy for tubercle by some process which could be divulged without the risk of the public being supplied either with material useless from its inertness, or, on the other hand, with deadly poisons. Koch, I believe, would not have published his method at all, had it not been for great pressure brought to bear upon him, until he could have produced it in a form capable of being rewealed in every detail. It is nothing but the fear that, by publishing now the precise mode of preparing this material, he might do immense harm instead of good that prevents him from making it known. And I must say that the carping against Koch on account of what is spoken of as a "secret remedy" can only proceed from absolute ignorance of the beautiful character of the man. But if it should so happen that, as with the other diseases to which II have referred, so with tubercle, complete immunity should be obtained by means of some inorganic chemical substance which anyone can prepare, then would be achieved the com plete triumph of the treatment of tuberculosis. And, for coy part, I rejoice that we are permitted to look forward with hope to that glorious consummation.

\section{ABSTRACT OF AN}

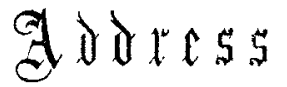

\section{THE CHARACTERISTIC ORGANISM OF CANCER.}

Read before the Pathologicat Society of Londen on Dec. And, and the Medico-Chirurgical Society of Edinburgh on Dec. Brd, 18\%),

By WILLIAM RUSSELI, M.D., F.R.C.P.E,

LECTURER ON PATHOLOGY IN TIE SCHOOL OF VIEICINY, AND PATHO-

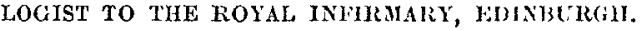

DR. Russell stated he had been occupied for some years in tracing the mode of growth of cancer in different organs. By this study he hoped to map out the steps of the process, and by learning the manner of its grow th to perhaps obtain an insight into the factors, determining the departure of the tissues from their normal behaviour and arrangements. He bad found appearances which he could not int into modes of cell growth and nuclear proliferation, and these had so puzzled him in one case that he asked his pathological assistant, Mr. W. F. Robertson, to experiment on it with every possible combination of stains with a view to the possible differentiation of some of these structures. His attempto were soon successful by the following method: 1. Saturated solution of fuchsine in a 2 per cent. carbolic acid in water, 2. 1 per cent. solution of iodine green
(Grüber's) in a 2 per cent. carbolic acid in water. Place section in water. Then stain in fuchsine for ten minutes or longer; wash for a few minutes in water. Then wash for half a minute in absolute alcohol. From this put the section into the solution of iodine green, and allow it to remain well spread out for five minutes. From this rapidly dehydrate in absolute alcohol, pass through oil of cloves, and mount in balsam. By this method it was found that certain structures stained a brilliant purplish-red, while the tissues stained green. Similar bodies were found in a number of cancers then examined, and these, for laboratory purposes, were called "fuchsine bodies."

With this discovery all kinds of possible errors suggested themselves. That they were not accidental impurities in material, bottles, or stains was shown by the fact that tissues from the same bottles and cut at the same time gave no indication of this. That they were not the nuclei of tissue cells in exaggerated reproductive activity was tested by the cells in organising inflammation of serons membranes not giving the reaction, nor the cells in tubercle, in typhoid lesion, in inflammatory affections, or in the organs of an embryo. That they were not globes of some degenerative substance was proved by the examination of a great variety of tissues showing different varieties of degeneration. Further, they were not present in the sarcomata, nor in simple tumours, such as fibromata, papillomata, myomata, \&c., nor in venereal warts and condylomata, nor in primary syphilitic sores. Sections of a tumour labelled adenoma of the mamma, and rich in adenomatous structures, and a gumma of the dura mater showed the bodies, but of the history of these cases he was ignorant. Another syphilitic case which had defied treatment, and in which there was extensive destructive lesion of the fauces and larynx and the bones of the vertebra behind the fauces, showed a few fuchsine bodies in sections of the larynx. Altogether tissues had been examined from fifty to sixty different cases selected with the purpose of subjecting the positive observations to the severest possible tests. The result was that fuchsine bodies were found in one case of chronic ulcer of the leg, one of tubercular disease of a joint with old sinuses, one of phenomenally severe, destructive, and intractable syphilitic lesion; and in two other cases, of which he had no record, one a case of mammary adenoma, and one a gummatous tumour of the meninges. He indicated possible explanations of these, and that they could not be regarded as sufficient to overthrow the other evidence.

Turning to the positive side of the question, forty-five cases of cancer had been examined, which included malignant epithelial growths of various structure, as epitheliomas of the lips and face, rodent ulcer, scirrbus of the mamma, both primary and recurrent; malignant adenoma of cervical glands, cancers of the stomach, liver, spleen, abdominal glands, supra-renal capsules, uterus, and ovaries. The pathological position of one of these was still uncertain; another was represented by sections dated 1885 ; in these two no fuchsine bodies were found, but in the remaining forty-three they were present. In individual sections they varied greatly in number, and it was noted that they occurred in special abundance in foci. They might be present in the small-celled infiltration at the margin of the cancer, amongst or in the epitbelial cells, in the stroma, or in the lymphatics. As a rule, they occurred in clusters or groups of two, ten, twenty, or more, and they almost always showed a clear space round them. In shape they were perfectly round. The commonest size was $4 \mu$, but they might be much smaller or larger. Examined by daylight tliey appeared homogeneous and structureless.

As there seemed to be no escape from regarding these structures as special organisms, which-so far at least as his pathological material was concerned-were practically confined to cancer, the question was, Were they animal or vegetable, and what was their mode of growth and reproduction? To answer this question it was necessary to consider the work which had been done, especially on the Continent, in the study of cancer. He then referred briefly and in detail to the various papers which bad appeared in French and German literature, in which it was contended that an animal parasite had been found in some cases of cancer. Summing this up and excluding molluscum contagiosum, it was found that Albarran, Darier, Thoma, Wickham, and Sjöbring had found in cancer an organism which they described as belonging to the protozos, while Thoma did not commit himself, and only Wickham and Sjöbring give figures to aid in forming 
a judgment on their contentions. He next pointed out the characters of the protozoa, more especially the psorospermix or coccidix, and indicated that according to the authorities these were unicellular organiems forming in their interior psorospermiar, which in turn developed spores which were usually sickle-shaped bodies, and became free parasites. To meet the necessity of this stage in their life, Sjïbring liad figured the spore formation in the cancers he examined. In short, looking at the work on this subject in the concrete, be regarded some of the figures as having nothing whatever to do with foreign organisms, that others were certainly misinterpreted, while some probably represented the organism with which he was dealing.

Returning to the consideration of the fuclisine bodies, they might be studied by the special method of staining given, or by logwood and eosine, or by Gram's method with methyl violet. Each group and most of the isolated individuals were surrounded by a clear area, often having the appearance of being bounded by a definite capsule. In so far as the isolated individuals were concerned one entered an epithelial cell; the protoplasm and the nucleus of which stained with $\log$ wood; while the foreign organism lay in a clear area or vacuole in the cell protoplasnt, to which there was no true capsule. Both in the epithelial masses and the vacuoles referred to there might in addition $b$ s small fuchsine bodies surrounded by a clear space, and bounded by a capsule or limiting structure. Further, it was to be noted that in the vacuoles there might be several fuchsine bodies; while in others the fuchsine body was granular and had lost its charactelistic staining reaction, and showed undoubted spores in its interior. In the epithelium it may also be noted that sone fuchsine bodies are surrounded by a vacuole, while others are not.

From the foregoing it might be contended that the organism in quescion was a protozonn, were it uot that in sections stained by Gram's method the mode of reproduction is shown quite diagrammatically. The large fuchsine body is seen to give out a small globular body, which increases its distance from the parent body but remains attached to it by a filament; this bud grows and gives off another and a short chain, or otber forms nay be productd. The small spores could also be seen in the interior of the lymphoid cells, or leucocytes in the infiltrated area, the effect, of this being $t$, clear up the protoplasm of the cell and to produce a clear space or vacuole with a limiting ring. This he thought was the mode of formation of what might be called the free encapsuled organism present amongst epithelial cells or lying in vacuoles. As to the appearances in the interior of epithelial cells, the foreign body at first had no vacuole round it, but ultimately developed one, and this was to be accounted for by its influence upon the surrounding protoplasm lead. ing to its classification. He said that there could be absolutely no doubt that the organism was a fungus which helonged to the sprouting fungi--Sprosspilze-- of Niigeli; but the proof of this was not to be readily found in every section, for the usual arrangement was in clusters, especia'ly as demonstrable by fuscline and indine green method, which he thought acted best when the organism was at a certain stage of its grow th.

In conclusion, he said that if the presence of this parasitic fungus in cancer was confirmed by other observers, we had found in it an organism whose nutrition, reproduction, and death in the tissue could bardly be conceived as occurring without producing changes not disproportionate to the anatomical changes present in cancer.

\section{ON THE}

\section{ADMINISTRATION OF CHLOROFORM.}

BY DUDLEY W. BUXTON, M.D., B S , M.R.C P.LONI. ADMINISTRATOR OF ANASTHETICS IN UNIVERSITY COLLEGE HOSPITAL.

ONF of the dangers of controversy is the almost inevitable crystallisation of the thoughts of those who advocate, or press, the negative of any question. There is certainly some fear in the present juncture lest the common-sense side of the chloroform question should be left out in the cold while we hotly discuss the modus operandi of its death-dealing properties. On the present occasion I hope to draw attention as concisely as possible to the various practical issues involved in my title. Chloroform, I take it, cannot, even if we would, be laid aside ; it possesses properties so valuable and so useful that it will, perhaps for ever, remain a favourite anresthetic with many operatin on surgeons and obstetricians. The main considerations, then, for practical men are: How far is it a dangerous agent, in what dof $\mathrm{s}$ its danger consist, and can this danger be abrogated or minimised so as appreciably to render the peril beyond ordinary computation either by methods of administration or other means. and, lastly, how does it compare, as far as absolute safety goes, when placed side by side with other anesthetics?

It may be said that the present time is hardly ripe for opening such an inquiry, since the subject is still to be further elucidated by the clinical report promised us by the Editors of THE LaNCET. But we should remember that from its very nature such a report must be devoid of personal colour, being statistical, so that the experiences of practical anæesthetists can neither forestall nor be devoid of value whatever may be the finding of THE LANCET Chloroform Inquiry. Death under chloroform is, unhappily, a frequent occurrence. We hear of a few deaths, probably not all, and if we accept 1 in 3000 as a working estimate of their frequency we are probably within tbe mark, although Surgeon Major Lawrie says he has given chloroform five or ten tines daily for fifteen years without a casualty-i.e., a mean of 40,000 anies thetics; and other exceptional estimates have been given by Bandens, 1 in 10,000 during the Crimean War, al 1 Hunter McGuire, 1 in 15,000 during the Secession War. These deaths may be due to-(1) impure chloroform; (2) careless anisthetisation; (3) careful but faulty methods - in any of which events the chloroform is not. to hlame : (4) the direct effect of the anasthetic, due to its intrinsic properties, ard unavoidable by care, skill, or the inost approved methods.

No. 1: The impurities of chloroform which may produce untoward effrets are fiee acid, free chlorine. These, however, always give rise to cougbing, and assail the nose of the administiator as well as the patient. Chloroform, when left for Jong exposed, liberates noxious fumes, and should in this case not be used; and chloroform, when givem in a room heated strongly by illuminating gas, also de. composes, and most pungent and irritating tumes are given off, but only the utmost carelessness could fail to detect such a state of things. I think we may take it that by far the greater number of cases of chloroform deaths occlir in public institutions, hospitals, \&c., where the drug is in constant use and for several patients. We may fairly say then that reason No. 1 accounts for but few cases.

No. 2 is probably a more common source of danger; and is one which is likely to be still more prolific of evil if the belief gets abroad, as a daily paper expressed it after the first authoritative statement, that the heart was unaffected by chloroform, that taking this anxsthetio possessed no more danger than taking a glass of whisky-andwater. If the contention of those who deny primary cardiac syncope as a possibility in chloroform narcosis be just, any method which ensured due respiration and a percentage of chloroform below 4 per cent. must he approved and be safe, unless the personal equation of the administrator coming in changes the safety to danger by his failing to watch the respiration \&c.

No. 3: Undoubtedly some methods are open to grave cavil, but by far the most common methods employed are the open method-viz, the use of lint or a towel_-Skinnens mask or Junker's apparatus, and these are not faulty in principle, although dangerous in that the administrator may through heedlessness lessen or increase the strength of the anæsthetic to a langerous extent.

No. 4: Chloroform kills, all admit, through respiratory paralysis; while observers are divided as to whether it also (a) allows death through reflex shock in a patient partly or wholly under its in Huence, or $(\beta)$ destroys life by directand primary heart syncope. Admittingonly that extinction ensues through respiratory paralysis, one party affirm, and so far justly if we admit their premisses, that the duties of the administrator are really free from anxiety; watch the respiration, say they, and if it fails take your measures promptly-artificial respiration undertaken before the heart has given out (secondary heart syncope) will lead to resuscitation. On the other hand, those who contend that chloroform kills directly through the heart teach us a mournful story. Take the utmost care, use the most perfect method in the most approved and conscientious fashion, watch for the inception of symptoms of danger and grapple promptly with the peril, and yet in spite of all a certain number of the patients will die. Both will admit the danger 